$\begin{array}{cc}\text { ACADEMIA ROMÂNĂ } & \begin{array}{c}\text { Rev. Roum. Chim., } \\ \mathbf{2 0 2 0} \text { 65(6), 553-558 }\end{array} \\ & \text { Revue Roumaine de Chimie } \\ \text { http://web.icf.ro/rrch/ } & \text { DOI: 10.33224/rrch.2020.65.6.04 }\end{array}$

\title{
CONSTRUCTION OF POLYNUCLEAR COPPER(II) COMPLEXES FROM MONO- AND BINUCLEAR MODULES
}

\author{
Andrei A. PATRASCU, Catalin MAXIM and Marius ANDRUH ${ }^{*}$ \\ Inorganic Chemistry Laboratory, Faculty of Chemistry, University of Bucharest, \\ Str. Dumbrava Rosie nr. 23, 020464-Bucharest, Roumania
}

Received January 8, 2020

A trinuclear complex and a $1 \mathrm{D}$ coordination polymer, $\left[\left\{\mathrm{Cu}_{2} \mathrm{~L}^{1}(\mu-\mathrm{OH})\right\}\left\{\mathrm{Cu}(2,5-\text { pydc })_{2}(\mathrm{dmf})\right\}\right] \cdot 4 \mathrm{H}_{2} \mathrm{O} \quad(\mathbf{1})$ and ${ }_{\infty}\left[\left\{\mathrm{Cu}_{2} \mathrm{~L}^{2}\right\}\left\{\mathrm{Cu}(2,5-\text { pydc })_{2}\left(\mathrm{OClO}_{3}\right)_{2}\right\}\right]\left[\mathrm{Cu}_{2} \mathrm{~L}^{2}\left(\mathrm{OH}_{2}\right)_{2}\right](2)$, have been assembled using two binuclear copper(II) complexes with an end-off-, and, respectively, macrocyclic Robson ligands, and a mononuclear metalloligand, $\left[\mathrm{Cu}(2,5-\mathrm{pydc})_{2}\right]^{2-}\left(\mathrm{HL}^{1}\right.$ and $\mathrm{H}_{2} \mathrm{~L}^{2}$ are bicompartmental Schiff-base ligands resulting from condensation reactions between 2,6-diformyl- $p$-cresol with $\mathrm{N}, \mathrm{N}$-dimethylethylenediamine and, respectively, ethylenediamine; 2,5pydc $^{2-}=$ the dianion of the 2,5-pyridyl-dicarboxilc acid). The crystal structures of the two compounds have been solved.

\section{INTRODUCTION}

The search for new synthetic routes leading to homo- and heterometallic polynuclear complexes is of high interest in coordination chemistry. The properties of the resulting compounds (magnetic, electric, biomimetic, catalytic, etc.) are strongly dependent on the number and topology of the metal centers. Consequently, one major requirement for a synthetic strategy is to allow a good control over the nuclearity of oligonuclear complexes, as well as over the dimensionality and topology in the case of the coordination polymers. ${ }^{1}$ Our synthetic strategy in the chemistry of polynuclear complexes is based on the employment of preformed bi- and trinuclear buildingblocks, which are further connected by neutral or anionic spacers (organic molecules or metalloligands). ${ }^{2}$ The binuclear building-blocks, which can be homo- and heterometallic, are easily assembled using compartmental ligands. ${ }^{3}$ As far as the metalloligands are concerned, they contain potentially bridging ligands, most frequently cyanido and oxalato, and have a high stability towards dissociation/substitution reactions. In this paper we report on two new complexes which are assembled using cationic binuclear copper(II) complexes and $\left[\mathrm{Cu}(2,5-\text { pydc })_{2}\right]^{2-}$ as a metalloligand $\left(2,5-\right.$ pydc $^{2-}=$ the deprotonated $2,5-$ pyridyl-dicarboxilc acid). This anionic complex (Scheme 1), with two carboxylate groups available for the interaction with other metal ions, is quite robust and efficient as a metalloligand. ${ }^{4}$

\section{EXPERIMENTAL}

Materials and methods

All reagents and solvents for synthesis were commercially purchased and used without any further purification. The binuclear complexes, $\left[\mathrm{Cu}_{2}(\mu-\mathrm{OH}) \mathrm{L}^{1}\right]\left(\mathrm{ClO}_{4}\right)_{2} \quad$ and $\left[\mathrm{Cu}_{2} \mathrm{~L}^{2}\left(\mathrm{H}_{2} \mathrm{O}\right)_{2}\right]\left(\mathrm{ClO}_{4}\right)_{2} \cdot 2 \mathrm{H}_{2} \mathrm{O}$ have been obtained following the general procedures reported in the literature. ${ }^{5}$ The

\footnotetext{
* Corresponding author: marius.andruh@dnt.ro
} 
mononuclear complex $\left[\mathrm{Cu}(2,5-\mathrm{pydcH})_{2}\right]$ has been synthesized through a procedure similar to that of the pyridine-2,4dicarboxylato analogue. .e, $6^{4}$

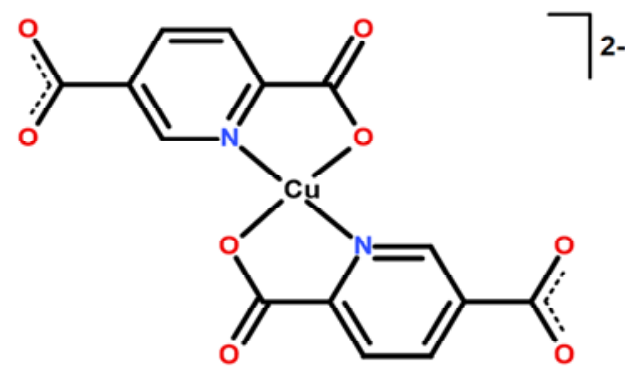

Scheme 1 below.

The two new compounds have been obtained as described

Compound 1. A water/methanol $(1: 2, \mathrm{v} / \mathrm{v})$ solution of $\mathrm{Cu}(2,5-\text { pydcH })_{2}$ and triethylamine (1:2 molar ratio) was added to a methanol/dmf solution of $\left[\mathrm{Cu}_{2} \mathrm{~L}^{1}(\mu-\mathrm{OH})\right]\left(\mathrm{ClO}_{4}\right)_{2} \quad(1: 1$ molar ratio). The resulted solution was stirred for one hour. After few days of slow evaporation, dark green crystals of $\left[\left\{\mathrm{Cu}_{2} \mathrm{~L}^{1}(\mu-\mathrm{OH})\right\}\left\{\mathrm{Cu}(2.5 \text {-pydc })_{2}(\mathrm{dmf})\right\}\right] \cdot 4 \mathrm{H}_{2} \mathrm{O} \quad$ (1) were obtained. FTIR (KBr pellets, $\left.\mathrm{cm}^{-1}\right): 3468(\mathrm{~m}), 3420(\mathrm{~m}), 2359$ (vw), 1635 (vs), 1622 (vs), 1541 (w), 1437 (vw), 1384 (vw),
1333 (m), 1273 (vw), 1233 (vw), 1121 (w), 1038 (w), 849 (vw), $764(\mathrm{vw}), 617(\mathrm{w}), 506 \mathrm{vw}), 409(\mathrm{w})$.

Compound 2. A water/methanol $(1: 2, \mathrm{v} / \mathrm{v})$ solution of $\mathrm{Cu}(2,5-$ pydcH $)_{2}$ and triethylamine $(1: 2$ molar ratio) was added to an methanol/dmf solution of $\left[\mathrm{Cu}_{2} \mathrm{~L}^{2}\left(\mathrm{H}_{2} \mathrm{O}\right)_{2}\right]\left(\mathrm{ClO}_{4}\right)_{2} \cdot 2 \mathrm{H}_{2} \mathrm{O}(1: 1$ molar ratio) and the resulted solution was stirred for one hour. Slow evaporation of the solution lead after several days to dark green crystals of ${ }_{\infty}^{1}\left[\left\{\mathrm{Cu}_{2} \mathrm{~L}^{2}\right\}\left\{\mathrm{Cu}(2,5 \text {-pydc })_{2}\left(\mathrm{OClO}_{3}\right)_{2}\right\}\right]\left[\mathrm{Cu}_{2} \mathrm{~L}^{2}\left(\mathrm{OH}_{2}\right)_{2}\right]$ (2). FTIR (KBr pellets, $\mathrm{cm}^{-1}$ ): $3422(\mathrm{w}), 2924$ (vw), 1641 (vs), 1619 (s), 1557 (w), 1459 (w), 1339 (s), 1277 (w), 1089(s), 1037 (vw), 900 (vw), 831 (w), 767 (w), 691 (vw), 665 (vw), 596 (vw), $533(\mathrm{vw}), 487$ (vw).

IR spectra were recorded on a FTIR Bruker Tensor V-37 spectrophotometer ( $\mathrm{KBr}$ pellets) in the range of 4000-400 $\mathrm{cm}^{-1}$. UV-Vis diffuse reflectance spectra were recorded on a JASCO V-670 spectrophotometer.

\section{X-Ray crystallography}

Suitable single crystals for crystallographic data collection were obtained by slow evaporation of the solvent, as described above. X-ray studies were performed on a STOE IPDS II diffractometer using graphite-monochromated Mo $\mathrm{K} \alpha$ radiation $(\lambda=0.71073 \AA)$. The structures were solved by direct methods and they were refined with the ShelXL refinement package. ${ }^{7}$ Data collection and refinement parameters for the two compounds are summarized in Table 1. CCDC reference numbers: 1972511 (1) and 1972512 (2).

Table 1

Crystallographic data for compounds $\mathbf{1}$ and $\mathbf{2}$

\begin{tabular}{|c|c|c|}
\hline Compound & 1 & 2 \\
\hline Formula & $\mathrm{C}_{34} \mathrm{H}_{49} \mathrm{~N}_{7} \mathrm{O}_{15} \mathrm{Cu}_{3}$ & $\mathrm{C}_{58} \mathrm{H}_{54} \mathrm{~N}_{10} \mathrm{O}_{22} \mathrm{Cl}_{2} \mathrm{Cu}_{5}$ \\
\hline Formula weight/ $\mathrm{g} \mathrm{mol}^{-1}$ & 986.42 & 1631.71 \\
\hline $\mathrm{T} / \mathrm{K}$ & $298(2)$ & $298(2)$ \\
\hline$\lambda / \AA$ & 0.71073 & 0.71073 \\
\hline Crystal system & Monoclinic & Triclinic \\
\hline Space group & $\mathrm{P} 21 / \mathrm{c}$ & $\mathrm{P}-1$ \\
\hline \multicolumn{3}{|l|}{ Unit cell } \\
\hline$a / \AA ̊$ & $18.700(4)$ & $10.799(2)$ \\
\hline$b / \AA$ & $8.4451(17)$ & $11.066(2)$ \\
\hline$c / \AA ̊$ & $26.044(5)$ & $12.978(3)$ \\
\hline$\alpha / \operatorname{deg}$ & 90 & $84.30(3)$ \\
\hline$\beta / \mathrm{deg}$ & $103.14(3)$ & $89.34(3)$ \\
\hline$\gamma / \operatorname{deg}$ & 90 & $75.41(3)$ \\
\hline$V / \AA^{3}$ & $4005.2(15)$ & $1493.2(6)$ \\
\hline$Z$ & 4 & 1 \\
\hline $\begin{array}{l}\text { Calculated density/ } \\
\qquad \mathrm{g} \mathrm{cm}^{-3}\end{array}$ & 1.634 & 1.815 \\
\hline Absorption coefficient $/ \mathrm{cm}-1$ & 1.656 & 1.933 \\
\hline$F(000)$ & 2032 & 827 \\
\hline Crystal size $/ \mathrm{mm} \times \mathrm{mm} \times \mathrm{mm}$ & $0.05 \times 0.04 \times 0.03$ & $0.03 \times 0.02 \times 0.01$ \\
\hline$\theta$ range $/$ deg & 2.156 to 25.000 & 2.490 to 25.000 \\
\hline Limiting indices & $\begin{array}{l}-22<\mathrm{h}<22 \\
-9<\mathrm{k}<10 \\
-30<1<30\end{array}$ & $\begin{array}{l}-12<\mathrm{h}<12 \\
-12<\mathrm{k}<12 \\
-15<1<15\end{array}$ \\
\hline Collected reflections & 39040 & 11255 \\
\hline Symmetry independent reflections & 6959 & 5025 \\
\hline $\mathrm{R}_{\text {int }}$ & 0.0920 & 0.1240 \\
\hline Completeness $/ \%$ & $95.9 \%$ & $93.0 \%$ \\
\hline Data/restraints/ parameters & $6959 / 8 / 564$ & $5025 / 2 / 466$ \\
\hline GOF on $\mathrm{F}^{2}$ & 1.031 & 0.960 \\
\hline Final $\mathrm{R}$ indices & $\mathrm{R} 1=0.0475$ & $\mathrm{R} 1=0.0665$ \\
\hline & $\mathrm{wR} 2=0.1240$ & $\mathrm{wR} 2=0.1535$ \\
\hline Largest diff peak and hole/e $\AA^{-3}$ & 1.248 and -1.339 & 1.298 and -1.299 \\
\hline
\end{tabular}




\section{RESULTS AND DISCUSSION}

The new complexes, $\left[\left\{\mathrm{Cu}_{2} \mathrm{~L}^{1}(\mu-\mathrm{OH})\right\}\{\mathrm{Cu}(2,5-\right.$ pydc $\left.\left.)_{2}(\mathrm{dmf})\right\}\right] \cdot 4 \mathrm{H}_{2} \mathrm{O}$ (1) and ${ }_{\infty}^{1}\left[\left\{\mathrm{Cu}_{2} \mathrm{~L}^{2}\right\}\{\mathrm{Cu}(2,5-\right.$ pydc $\left.\left.)_{2}\left(\mathrm{OClO}_{3}\right)_{2}\right\}\right]\left[\mathrm{Cu}_{2} \mathrm{~L}^{2}\left(\mathrm{OH}_{2}\right)_{2}\right]$ (2), have been obtained using two binuclear copper(II) complexes with an end-off-, and, respectively, macrocyclic Robson ligand (Scheme 2). Both Schiff-base proligands $\mathrm{HL}^{1}$ and $\mathrm{H}_{2} \mathrm{~L}^{2}$, are obtained from 2,6diformyl-p-cresol and diamines (N,N-dimethylethylenediamine and, respectively, ethylenediamine). The self-assembly processes between the two binuclear complexes and $\left[\mathrm{Cu}(2,5-\text { pydc })_{2}\right]^{2-}$ afford a trinuclear complex, $\mathbf{1}$, and a 1D coordination polymer, 2 . The metalloligand is generated in situ by deprotonation of $\left[\mathrm{Cu}(2,5-\mathrm{pydcH})_{2}\right]$ with triethylamine. The structures of the resulting compounds seem to be directed by the nature of the binuclear modules, which are obtained using an end-off (in 1) and a macrocyclic compartmental ligand (in 2). The crystal structures of the two compounds have been solved. The two modules in compound $\mathbf{1}$, mono- and binuclear, are connected via one carboxylato group arising from the metalloligand (syn-syn-bidentate bridging mode) Figure 1a. The two copper ions within the binuclear moiety show a square pyramidal geometry, with two nitrogen and two oxygen atoms from the phonoxido and hydroxido groups forming the basal plane $(\mathrm{Cu}(1)$ - $\mathrm{N}(1)=1.931(3), \mathrm{Cu}(1)-\mathrm{N}(2)=2.011(4), \mathrm{Cu}(1)-$ $\mathrm{O}(1)=1.959(3), \mathrm{Cu}(1)-\mathrm{O}(2)=1.925(3)$ and $\mathrm{Cu}(2)-$ $\mathrm{N}(3)=1.929(3), \mathrm{Cu}(2)-\mathrm{N}(4)=2.023(3), \mathrm{Cu}(2)-$ $\mathrm{O}(1)=1.970(3), \mathrm{Cu}(2)-\mathrm{O}(2)=1.919(3) \AA)$ and two carboxylato oxygen atoms into the apical positions $(\mathrm{Cu}(1)-\mathrm{O}(3)=2.543(3)$ and $\mathrm{Cu}(2)-\mathrm{O}(4)=2.503(3)$ $\AA)$. The copper ion within the metalloligand moiety also shown a square pyramidal geometry: two nitrogen and two carboxylato oxygen atoms form the two 2,5-pydc ${ }^{2-}$ ligands in basal plane $(\mathrm{Cu}(3)-\mathrm{N}(5)=$ 1.983(3), $\mathrm{Cu}(3)-\mathrm{N}(6)=1.998(3), \mathrm{Cu}(3)-\mathrm{O}(5)=$ 1.941(3), $\mathrm{Cu}(3)-\mathrm{O}(7)=1.938(3) \AA)$, while the apical position is occupied by the oxygen atom arising from one dmf molecule $(\mathrm{Cu}(3)-\mathrm{O}(11)=2.410(3) \AA)$. One of the pyridyl rings from the metalloligand and the phenyl group from the binuclear moiety are involved in intramolecular $\pi-\pi$ stacking interactions (3.49 $\AA$ ). The crystallization water molecules and the trinuclear complexes are connected in the crystal by hydrogen bonds (Figure 1b).

The crystallographic investigation of compound 2 reveals linear anionic chains and discrete binuclear cations (Figure 2). The anionic chains are assembled from binuclear modules (nodes), $\left\{\mathrm{Cu}_{2} \mathrm{~L}^{2}\right\}$, which are connected by $\{\mathrm{Cu}(2,5-$ pydc) $\left.)_{2}\left(\mathrm{OClO}_{3}\right)_{2}\right\}$ units acting as divergent (exodentate) ligands (spacers). Within the binuclear units, the copper ions are pentacoordinated with a square pyramidal geometry: two nitrogen and two oxygen atoms arising from each compartment of the organic ligand $(\mathrm{Cu}(1)-\mathrm{N}(1)=1.908(8), \mathrm{Cu}(1)$ - $\mathrm{N}(2)=1.916(7), \mathrm{Cu}(1)-\mathrm{O}(1)=1.935(6), \mathrm{Cu}(1)-$ $\mathrm{O}(1) \# 1=1.916(6) \AA, \# 1=1-x, 1-y, 1-z)$ in the basal plane and, into the apical position, an oxygen atom arising from the monodentate carboxylato group belonging to the $\left\{\mathrm{Cu}(2,5-\mathrm{pydc})_{2}\left(\mathrm{OClO}_{3}\right)_{2}\right\}$ unit $(\mathrm{Cu}(1)-\mathrm{O}(2)=2.243(6) \AA)$. The copper atom within the mononuclear spacer, $\{\mathrm{Cu}(2,5-$ pydc $\left.)_{2}\left(\mathrm{OClO}_{3}\right)_{2}\right\}$, is hexacoordinated, with an elongated octahedral geometry: the equatorial plane is formed by two pyridyl nitrogens and two carboxylato oxygen atoms $(\mathrm{Cu}(2)-\mathrm{N}(3)=$ 1.976(7), $\mathrm{Cu}(2)-\mathrm{N}(3) \# 3=1.976(7), \mathrm{Cu}(2)-\mathrm{O}(4)$ $=1.951(6), \mathrm{Cu}(2)-\mathrm{O}(4) \# 3=1.951(6) \AA, \# 3=-x$, $1-y,-z)$, while the axial positions are occupied by two perchlorato ligands $(\mathrm{Cu}(2)-\mathrm{O}(10) \# 2=$ 2.612(2) and $\mathrm{Cu}(2)-\mathrm{O}(10) \# 3=2.612(2) \AA)$. As far as the discrete binuclear cations are concerned, they contain pentacoordinated copper ions, with a square pyramidal geometry, the apical positions being occupied by aqua ligands $(\mathrm{O}(1 \mathrm{~W})-\mathrm{Cu}(3)=$ $\mathrm{O}(1 \mathrm{~W}) \# 2-\mathrm{Cu}(3) \# 2=2.276(7) \AA, \# 2=-x,-y, 1-$ $z$ ). One carboxylate oxygen atom from the $\left\{\mathrm{Cu}(2,5-\text { pydc })_{2}\left(\mathrm{OClO}_{3}\right)_{2}\right\}$ unit is hydrogen bonded to the aqua ligand arising from the discrete binuclear cation (Figure 2). Selected bond distances and angles for compounds $\mathbf{1}$ and $\mathbf{2}$ are gathered in Table 2.

The UV-visible spectra of the two compounds (Figure 3) show large bands, resulted from the presence of different copper(II) chromophores within each compound.

In conclusion, the examples presented herein show that the copper-based metalloligand, $[\mathrm{Cu}(2,5-$ pydc $\left.)_{2}\right]^{2}$, has a very interesting potential in the synthesis of multimetallic complexes. The nature of the assembling binuclear complex cations seems to play an important role on the aggregation of various systems: oligonuclear complexes or coordination polymers. 


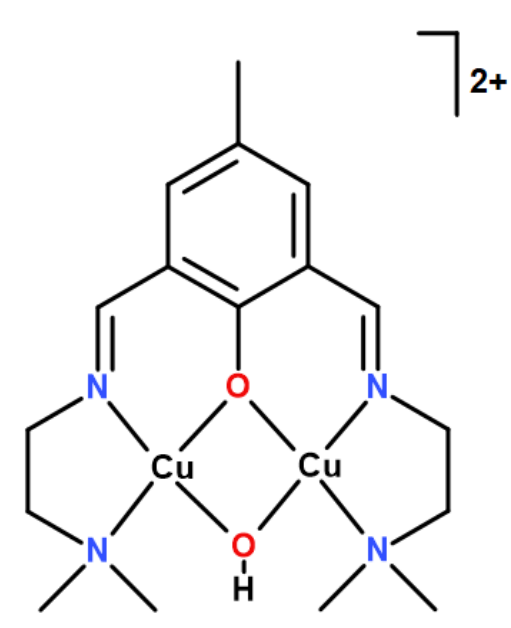

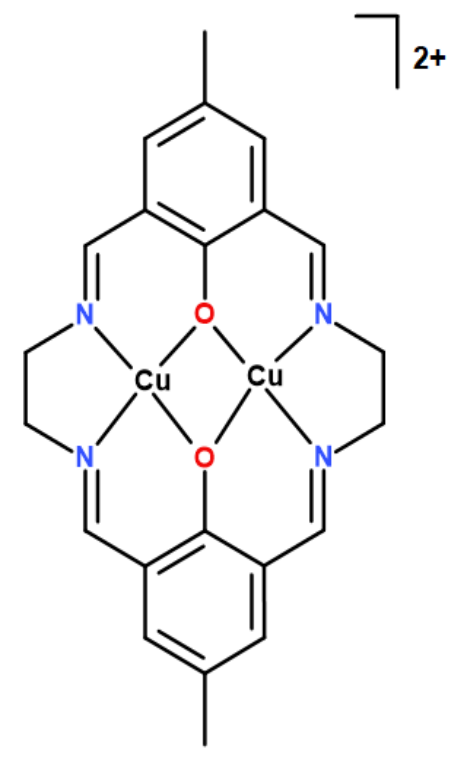

Scheme 2

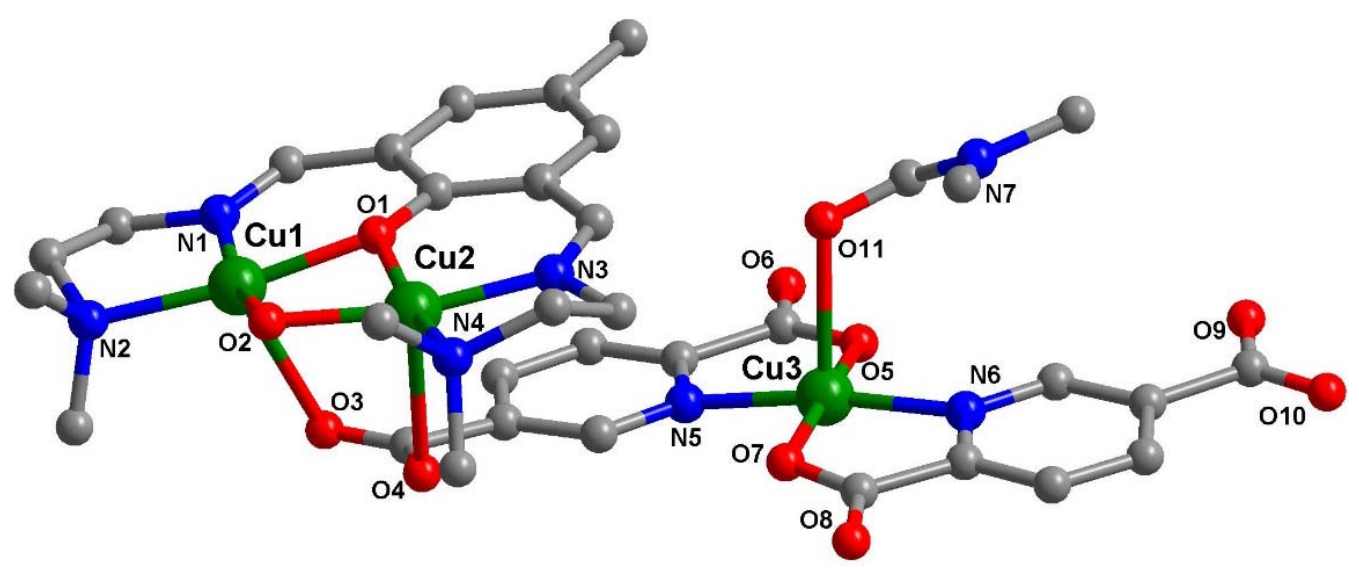

(a)

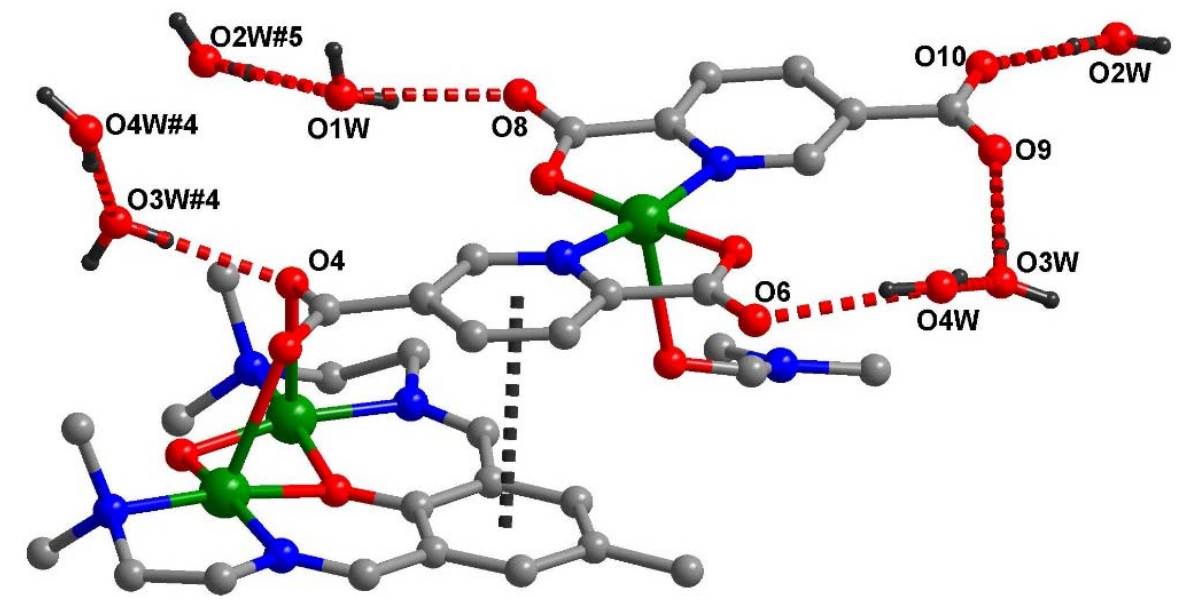

(b)

Fig. 1 - (a) Crystal structure of the trinuclear complex 1, along with atom numbering scheme; (b) Hydrogen bond interactions involving the trinuclear complex and the crystallization water molecules : O $8-\mathrm{O} 1 \mathrm{~W}=2.831(5)$; O1W $-\mathrm{O} 2 \mathrm{~W} \# 5=2.814(5)$; $\mathrm{O} 4-\mathrm{O} 3 \mathrm{~W} \# 4=2.832(5) ; \mathrm{O} 3 \mathrm{~W} \# 4-\mathrm{O} 4 \mathrm{~W} \# 4=2.830(6) ; \mathrm{O} 6-\mathrm{O} 4 \mathrm{~W}=2.884(6) ; \mathrm{O} 4 \mathrm{~W}-\mathrm{O} 3 \mathrm{~W}=2.830(6) ; \mathrm{O} 3 \mathrm{~W}-\mathrm{O} 9=2.748(5)$; $\mathrm{O} 10-\mathrm{O} 2 \mathrm{~W}=2.848(6) \AA ; \# 4=x, 1.5-y, 0.5+z ; \# 5=x, 0.5-y, 0.5+z . \pi-\pi$ stacking interactions are established between one of the pyridyl rings from the metalloligand and the phenyl moiety of the binuclear module. 


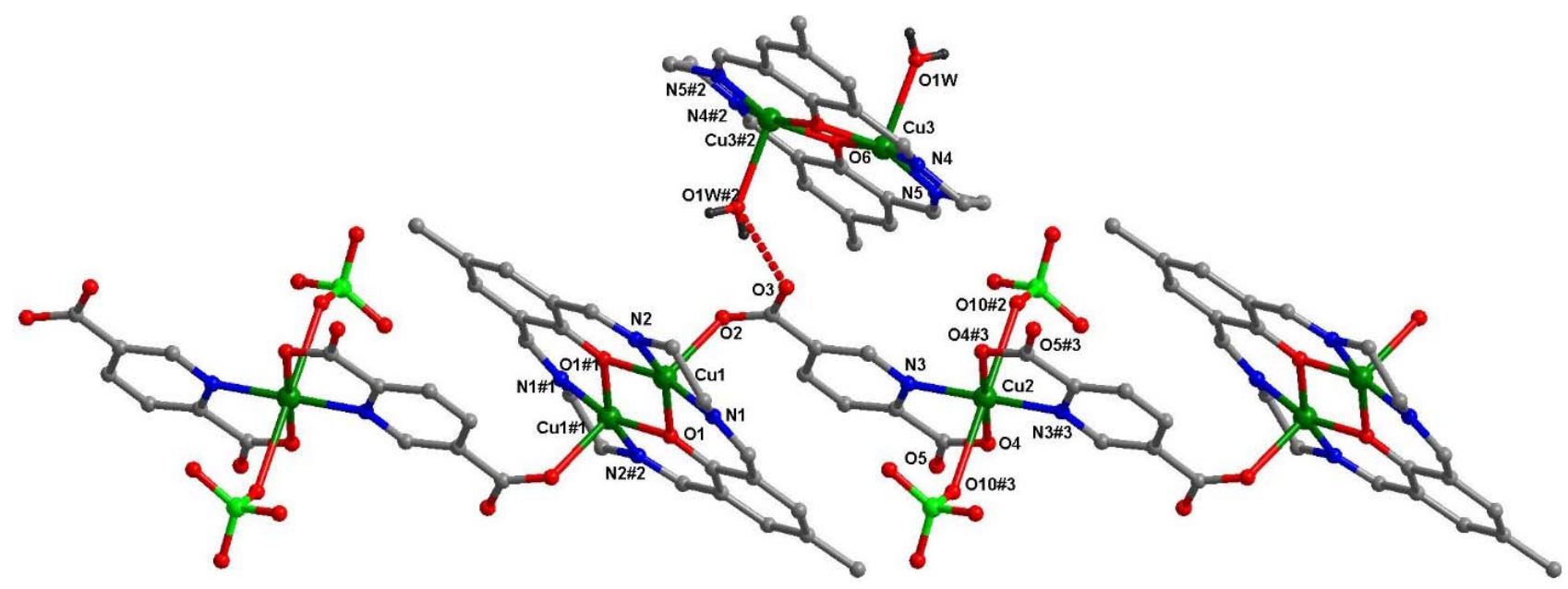

Fig. 2 - Crystal structure of the 1D coordination polymer in compound 2, showing the H-bond interaction established between one carboxylato oxygen atoms and the aqua ligand coordinated to a copper(II) ion from the binuclear cation $(\mathrm{O} 3-\mathrm{O} 1 \mathrm{~W} \# 2=2.735(8) \AA)$.

Table 2

Selected bond lengths $(\AA)$ and angles $\left(^{\circ}\right)$ for compound $\mathbf{1}$ and $\mathbf{2}$

\begin{tabular}{|c|c|c|}
\hline 1 (distances) & 1 (angles) & 2 (distances) \\
\hline $\mathrm{N}(1)-\mathrm{Cu}(1)=1.931(3)$ & $\mathrm{O}(1)-\mathrm{Cu}(1)-\mathrm{O}(2)=79.04(11)$ & $\mathrm{N}(1)-\mathrm{Cu}(1)=1.908(8)$ \\
\hline $\mathrm{N}(2)-\mathrm{Cu}(1)=2.011(4)$ & $\mathrm{O}(1)-\mathrm{Cu}(1)-\mathrm{O}(3)=82.631(11)$ & $\mathrm{N}(2)-\mathrm{Cu}(1)=1.916(7)$ \\
\hline $\mathrm{O}(1)-\mathrm{Cu}(1)=1.959(3)$ & $\mathrm{O}(1)-\mathrm{Cu}(1)-\mathrm{N}(1)=91.35(13)$ & $\mathrm{O}(1)-\mathrm{Cu}(1)=1.935(6)$ \\
\hline $\mathrm{O}(2)-\mathrm{Cu}(1)=1.925(3)$ & $\mathrm{O}(1)-\mathrm{Cu}(1)-\mathrm{N}(2)=173.04(15)$ & $\mathrm{O}(1) \# 1-\mathrm{Cu}(1)=1.916(6)$ \\
\hline $\mathrm{O}(3)-\mathrm{Cu}(1)=2.543(3)$ & $\mathrm{O}(2)-\mathrm{Cu}(1)-\mathrm{N}(1)=164.65(13)$ & $\mathrm{O}(2)-\mathrm{Cu}(1)=2.243(6)$ \\
\hline $\mathrm{N}(3)-\mathrm{Cu}(2)=1.929(3)$ & $\mathrm{O}(2)-\mathrm{Cu}(1)-\mathrm{N}(2)=101.90(14)$ & $\mathrm{N}(3)-\mathrm{Cu}(2)=1.976(7)$ \\
\hline $\mathrm{N}(4)-\mathrm{Cu}(2)=2.023(3)$ & $\mathrm{O}(2)-\mathrm{Cu}(1)-\mathrm{O}(3)=101.333(11)$ & $\mathrm{N}(3) \# 3-\mathrm{Cu}(2)=1.976(7)$ \\
\hline $\mathrm{O}(1)-\mathrm{Cu}(2)=1.970(3)$ & $\mathrm{N}(1)-\mathrm{Cu}(1)-\mathrm{N}(2)=86.23(15)$ & $\mathrm{O}(4)-\mathrm{Cu}(2)=1.951(6)$ \\
\hline $\mathrm{O}(2)-\mathrm{Cu}(2)=1.919(3)$ & $\mathrm{N}(1)-\mathrm{Cu}(1)-\mathrm{O}(3)=89.116(11)$ & $\mathrm{O}(4) \# 3-\mathrm{Cu}(2)=1.951(6)$ \\
\hline $\mathrm{O}(4)-\mathrm{Cu}(2)=2.503(3)$ & $\mathrm{N}(2)-\mathrm{Cu}(1)-\mathrm{O}(3)=103.837(14)$ & $\mathrm{O}(10) \# 2-\mathrm{Cu}(2)=2.612(2)$ \\
\hline $\mathrm{N}(5)-\mathrm{Cu}(3)=1.983(3)$ & $\mathrm{O}(1)-\mathrm{Cu}(2)-\mathrm{O}(2)=78.91(11)$ & $\mathrm{O}(10) \# 3-\mathrm{Cu}(2)=2.612(2)$ \\
\hline $\mathrm{N}(6)-\mathrm{Cu}(3)=1.998(3)$ & $\mathrm{O}(1)-\mathrm{Cu}(2)-\mathrm{N}(3)=90.52(13)$ & $\mathrm{N}(4)-\mathrm{Cu}(3)=1.915(7)$ \\
\hline $\mathrm{O}(5)-\mathrm{Cu}(3)=1.941(3)$ & $\mathrm{O}(1)-\mathrm{Cu}(2)-\mathrm{N}(4)=167.60(13)$ & $\mathrm{N}(5)-\mathrm{Cu}(3)=1.906(7)$ \\
\hline $\mathrm{O}(7)-\mathrm{Cu}(3)=1.938(3)$ & $\mathrm{O}(1)-\mathrm{Cu}(2)-\mathrm{O}(4)=90.190(10)$ & $\mathrm{O}(6)-\mathrm{Cu}(3)=1.927(6)$ \\
\hline \multirow[t]{14}{*}{$\mathrm{O}(11)-\mathrm{Cu}(3)=2.410(3)$} & $\mathrm{O}(2)-\mathrm{Cu}(2)-\mathrm{N}(3)=168.23(13)$ & $\mathrm{O}(1 \mathrm{~W})-\mathrm{Cu}(3)=2.276(7)$ \\
\hline & $\mathrm{O}(2)-\mathrm{Cu}(2)-\mathrm{N}(4)=103.02(12)$ & $\mathrm{O}(6) \# 2-\mathrm{Cu}(3)=1.926(7)$ \\
\hline & $\mathrm{O}(2)-\mathrm{Cu}(2)-\mathrm{O}(4)=89.532(10)$ & $\mathrm{O}(1 \mathrm{~W}) \# 2-\mathrm{Cu}(3) \# 2=2.276(7)$ \\
\hline & $\mathrm{O}(5)-\mathrm{Cu}(3)-\mathrm{O}(7)=173.84(12)$ & \\
\hline & $\mathrm{O}(5)-\mathrm{Cu}(3)-\mathrm{N}(5)=83.68(12)$ & \\
\hline & $\mathrm{O}(5)-\mathrm{Cu}(3)-\mathrm{N}(6)=98.98(12)$ & \\
\hline & $\mathrm{O}(5)-\mathrm{Cu}(3)-\mathrm{O}(11)=86.04(13)$ & \\
\hline & $\mathrm{O}(7)-\mathrm{Cu}(3)-\mathrm{N}(5)=93.05(12)$ & \\
\hline & $\mathrm{O}(7)-\mathrm{Cu}(3)-\mathrm{N}(6)=83.57(12)$ & \\
\hline & $\mathrm{O}(7)-\mathrm{Cu}(3)-\mathrm{O}(11)=99.63(13)$ & \\
\hline & $\mathrm{N}(5)-\mathrm{Cu}(3)-\mathrm{N}(6)=171.90(13)$ & \\
\hline & $\mathrm{N}(5)-\mathrm{Cu}(3)-\mathrm{O}(11)=98.50(12)$ & $\# 1=1-x, 1-y, 1-z$ \\
\hline & $\mathrm{N}(6)-\mathrm{Cu}(3)-\mathrm{O}(11)=89.34(12)$ & $\# 2=-x,-y, 1-z$ \\
\hline & & $\# 3=-x, 1-y,-z$ \\
\hline
\end{tabular}




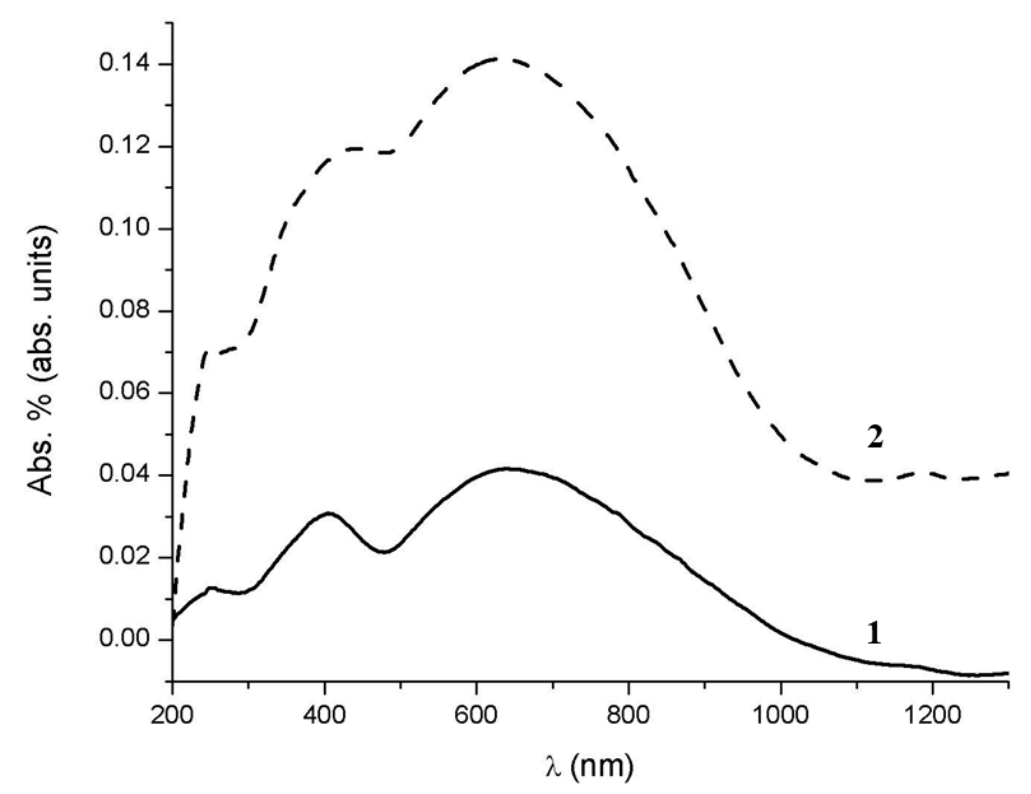

Fig. 3 - Diffuse reflectance spectra of compounds $\mathbf{1}$ and $\mathbf{2}$

\section{REFERENCES}

1. See, for example: (a) G. E. Kostakis and A. K. Powell, Chem. Eur. J., 2010, 16, 7983; (b) K. E. Kostakis, S. P. Perlepes, V. A. Blatov, D. M. Proserpio and A. K. Powell, Coord. Chem. Rev., 2012, 256, 1246; (c) B.-H. Ye, M.-L. Tong and X.-M. Chen, Coord. Chem. Rev., 2005, 249, 545; (d) M. Li, D. Li, M. O'Keeffe and O. M. Yaghi, Chem. Rev., 2014, 114, 1343; (e) R. Robson, Dalton Trans., 2008, 5113; (f) C. Janiak and J. K. Vieth, New J. Chem., 2010, 34, 2366.

2. (a) M. Andruh, Pure Appl. Chem., 2005, 77, 1685; (b) M. Andruh, Chem. Commun., 2007, 2565; (c) T. Mocanu, V. Tudor and M. Andruh, CrystEngComm, 2017, 19, 3538.

3. (a) M. Andruh, Chem. Commun., 2011, 47, 3025; (b) M. Andruh, D. G. Branzea, R. Gheorghe and A. M. Madalan, CrystEngComm, 2009, 11, 2571.

4. (a) B. O. Patrick, C. L. Stevens, A. Storr and R. C. Thompson, Polyhedron, 2005, 24, 2242; (b) Y. Liang, R. Cao, W. Su, M. Hong and W. Zhang, Angew. Chem., Int. Ed., 2000, 39, 3304; (c) Y. Liang, M. Hong, W. Su, R. Cao and W. Zhang, Inorg. Chem., 2001, 40, 4574; (d) L.
Xue, F. Luo, Y.-X. Che and J.-M. Zheng, J. Molec. Struct., 2007, 832, 132; (e) C. D. Ene, C. Maxim, F. Tuna and M. Andruh, Inorg. Chim. Acta, 2009, 362, 1660. (f) J. Y. Lu and V. Schauss, CrystEngComm, 2002, 4, 623; (g) S. S. Massoud, F. R. Louka, M. A. Gazzaz, M. M. Henary, R. C. Fischer and F. A. Mautner, Polyhedron, 2016, 111, 45; (h) C. Mohapatra and V. Chandrasekhar, Cryst. Growth \& Des., 2014, 14, 406; (i) B. Rajasekhar, N. Bodavarapu, M. Sridevi, G. Thamizhselvi, K. Rizha Nazar, R. Padmanaban and T. Swu, J. Mol. Struct., 2018, 1156, 690; (j) K. Shankar, B. Das and J. B. Baruah, RSC $A d v$. 2013, 3, 26220; (k) Y. Sun, X. Gu, F. Ding, P. F. Smet, E. Gao, D. Poelman and F. Verpoort, Cryst. Growth \& Des., 2010, 10, 1059; (1) D.-E. Wang, Z.-F. Tian, Feng Wang, L.-L. Wen and D.-F. Li, J. Inorg. Organomet. Polym., 2009, 19, 196.

5. (a) J. J. Grzybowski, P. H. Merrell and F. L. Urbach, Inorg. Chem. 1978, 11, 3078; (b) N. H. Pilkington and R. Robson, Aust. J. Chem. 1970, 23, 2225

6. S. Noro, H. Miyasaka, S. Kitagawa, T. Wada, T. Okubo, M. Yamashita and T. Mitani, Inorg. Chem. 2005, 44,133.

7. G. M. Sheldrick, Acta Cryst., 2015, C71, 3. 